Saint Louis University School of Law

Scholarship Commons

All Faculty Scholarship

1985

\title{
State Regulation of Long-Term Care: A Decade of Experience with Intermediate Sanctions
}

Sandra H. Johnson

Saint Louis University School of Law

Follow this and additional works at: https://scholarship.law.slu.edu/faculty

Part of the Health Law and Policy Commons

\section{Recommended Citation}

Johnson, Sandra H., State Regulation of Long-Term Care: A Decade of Experience with Intermediate Sanctions (September, 13 2010). National Senior Citizens Law Center, State Intermediate Sanctions for Nursing Homes, 1988.

This Article is brought to you for free and open access by Scholarship Commons. It has been accepted for inclusion in All Faculty Scholarship by an authorized administrator of Scholarship Commons. For more information, please contact erika.cohn@slu.edu, ingah.daviscrawford@slu.edu. 


\section{State Regulation of Long-Term Care: A Decade of Experience with Intermediate Sanctions}

by Sandra H. Johnson, J.D., LL.M.

$\mathbf{R}$ home regulations have created an ar ray of enforcement tools that relate the severity of the penalty to the severity of the violation. ${ }^{1}$ These intermediate sanctions, intended to be flexible and effective in enforcing state standards, include civil fines, re ceiverships, public disclosure, monitors, and suspension of admissions. As supplements to the more traditional remedy of license revocation, intermediate sanctions can enforce standards without closing facilities unnecessarily, thus avoiding trauma to the residents, ${ }^{2}$ aggravation of the

Ms. Jobnson is Professor of Law at the Saint Louis University Scbool of Law in Saint Louis, Missouri, and Assistant Professor of Law in Internal Medicine at the University's Scbool of Medicine. She is also affiliated with the Center for Health Law Studies at the University and a member of the Board of Editors of Law, Medicine \& Health Care. The original draft of this paper was commissioned under contract by the Institute of Medicine of the National Academy' of Sciences in Wasbington, D.C., as part of their study of nursing bome regulation that was funded by the Health Care Financing Administration of the United States Department of Health and Human Services (Contract Number 500 83-0054). The National Academy' of Sciences bas given permission to pub. lish this paper, but the opinions contained berein are those of the author and not those of the National Academy of Sciences, the Institute of Medicine, its committee to study nursing bome regulation, or the federal government. shortage of nursing home beds, ${ }^{3}$ and lengthy administrative proceedings and litigation. ${ }^{4}$

The study of nursing home regulation by the Institute of Medicine of the National Academy of Sciences of fers a unique opportunity to evaluate the implementation of intermediate sanctions by the states over the past decade. Because of the high degree of similarity among the state statutes authorizing these sanctions, compari sons can be drawn. The differences among state statutes and agency practices provide informative contrasts in experience that contribute to the evaluation. This article focuses primarily on the states' utilization of the sanctions and recommends modifications in the structure of the enforcement tools and in enforcement practices in light of this experience.

This article's presentation is not statistical and does not discuss a particular state's experience in detail. Rather, it highlights common experiences shared by several states as these experiences have emerged in interviews, the Institute of Medicine case studies and other sources. ${ }^{5}$ Each section includes recommendations for enhancing the effectiveness of sanctions. The final section of the article suggests the role that the federal government might play in light of the states' activities.

\section{Legal Challenges to State Intermediate Sanctions}

In virtually every state, the implementation of the new intermediate sanctions has produced litigation testing the enforcement authority of the state and the constitutionality of the new statutes. Although the theories under- lying the legal challenges to state en forcement of nursing home laws cover a broad range, ${ }^{6}$ among those most often used against state enforcement are unconstitutional delegation of legislative authority and vagueness. A brief examination of these theories and the cases litigated under them ${ }^{?}$ supports some recommendations for the enhancement of the capacity of state statutes and enforcement practices to withstand structural challenges.

\section{Unconstitutional Delegation of Legislative Authority}

The state's authority to regulate nurs ing homes arises primarily from the police power, which empowers the state to protect the health, safety, and welfare of the community. ${ }^{8}$ A city or county government may exercise the state's police power and regulate nursing homes, but only to the extent that the state has delegated that power to the inferior governmental entity.

The legislature is the body authorized to make laws under the police power. Delegations of this legislative authority, such as the delegation of rulemaking to administrative agencies, are invalid unless the legislature establishes standards to govern the ageney's activities.

While it is both inadvisable and impractical for the legislature to estab. lish detailed standards for administrative rulemaking, the delegation doctrine requires that some general standard be included in the statute. ${ }^{10}$ Claims that the legislature is incompetent to set standards in the public health setting have not persuaded courts that statutes need not specify 
general standards, " but a simple di rective that the agency ensure the fitness and adequacy of the facility has received approval from at least one court. ${ }^{12}$ Cases in which a statute has been successfully challenged as an unconstitutional delegation have involved statutes containing absolutely no standard for agency rulemaking. ${ }^{13}$

The doctrine of unconstitutional delegation of legislative authority is all but extinct in the federal system, but state courts still apply the doctrine to state statutes and administra tive regulations. The inconsistent ap)plication of the doctrine by state courts and the doctrine's own merely formalistic requirements warant its death in the state system as well. As long as the docrine is in existence, however, state statutes must contain at least generally descriptive standards for agency authority

\section{Statutory Vagueness}

Another side of the problem of the lack of specificity of statutes is the claim that the statute is vague and thus does not give sufficient notice to the facility of the conduct expected of it. The weakness of this challenge should be apparent. While the statute may not have the detail reguired for adequate notice to the facility, the ad. ministrative regulations typically specify the requirements. ${ }^{1-}$

Claims that the administrative regu lations themselves are vague are more problematic. Proviclers consistently criticize the vagueness of regulations. For example, an atorney representing facilities in fllinois has criticized a rule prohibiting the actmission of a resident "with a communicable, con tagious, or infectious discase" as vague: "I don't know what communicable' means or 'contagious' or 'infectious" within the language of this rule, and I don't know who is to determine that. Now if that rule said 'contagious, communicable, or infectious discases as determined by the resident's physician or the facility's physician' that would be fine." 15

A constant pressure for specificity has pushed regulatory agencies to ward quantifiable measurements of the quality of care. As state agencies move toward more quantifiable indi cators, however, they are criticized as focusing too much on checklists, and not enough on patient care. The Illinois Association of Homes for the Ag ing, for example, has testified at a public hearing that "excessive detail in all sets of standards should be re. moved." 16 The problem of balancing the acute limitations of quantification of standards with the facilities' and agencies' need for predictability and consistency is a recurring issue in "quality-of-care" regulation.

The essential dispute, however, does not concern vagueness, although that is the label often applied; rather, it usually concerns the discretion nec essarily allowed to surveyors. Imple mentation of even the most detailed rules requires some discretion. The exercise of judgment cannot be eliminated, and absolute uniformity of application cannot be achieved; but the unfair inconsistency in application, often criticized by nursing home ad. ministrators, ${ }^{1-}$ diminishes regulatory effectiveness and the success of en-

\section{Civil fines are among the most effective of the inter- mediate sanctions.}

forcement efforts. Consistency, how ever, does not require that all facilities be treated alike, because facilities differ in relevant aspects, including the existence of repetitive violations, patterns of violations, general decline, and history of temporary correction of deficiencies. In light of these differences, it may be justifiable that a defi ciency is cited against one facility but not against another. Antiquated infor mation systems seriously hamper many states in their efforts to monitor and achieve consistency in the use of flexible enforcement tools that relate to differences among facilities and that require coordination of field ac tivity and the several levels of en forcement.

\section{Intermediate Sanctions and Classification of Violations}

Implicit in the development of intermediate sancions is the assumption that the severity of sanctions must relate to the seriousness of the viola tions. Classification of violations makes the relationship between viola tion and penalty more predictable and enhances the deterrant or disin centive effect of the sanctions

Several revised nursing home stat utes provide for classification or ranking of violations according to serious ness. ${ }^{14}$ Other states implement classi. fication by regulation. ${ }^{19}$ Most states that classify violations use very few classifications (typically three) and establish only broad categories that relate primarily to the impact of the violations on the health and safety of the residents. ${ }^{20}$ While the statute may restrict a particular sanction to a cer tain class of violations, the administra tive agency generally has authority to classify the specific violations.

Some observations on the relationship between classification schemes and sanctions are appropriate in as. sessing the effectiveness of intermediate sanctions. First, a classification system does not adequately account for the severity of deficiencies and their impact on the health and safery of nursing home residents unless the system allows specific violations to be deemed more serious in light of the facility's pattern of deficiencies, repetition of particular violations, and other underlying problems, such as insolvency or bankruptcy. Authority to weigh these factors solely by assess ing the amount of a fine is insufficient if the range of fines available for a particular classification scheme is narrow. Adjusting the amount of the fine cannot completely remedy the inade. quacy of a classification scheme that fails to account for a pattern of deficiencies, repeated violations, or other problems, however, because the statutory classification scheme may also determine the availability of other remedies, such as receivership. Second, a classification scheme that re volves entirely around the impact of a violation on the health and safety of the residents may be subject to nar. row interpretation if challenged and may exclude certain violations, for ex. ample, infractions of residents' rights provisions, from sanctions. Both of these observations are discussed further in the context of particular sanctions. The first is discussed in the fol lowing section on civil fines and the 
second, in the section on the enforcement of residents' personal rights.

\section{Civil Fines}

Among the most effective of the intermediate sanctions are civil fines. With an appropriate range, the amount of the fine can be sensitive to the severity of the particular violation and the history of the facility. ${ }^{21}$ Unlike other sanctions, civil penalties can be swiftly enforced, unencumbered by lengthy litigation delays. ${ }^{22}$ To the extent that substandard care is economically motivated, civil fines can in. crease the cost and decrease the ben-

\section{Adjusting the amount of the fine cannot completely rem- edy the inadequacy of a classi- fication scheme that fails to account for a pattern of defi- ciencies, repeated violations, or other problems.}

efit of socially undesirable behavior. Of course, where a violation is attributable to the poor financial condition of a facility or to incompetent management, civil fines probably will be ineffective in changing the particular behavior involved. In conjunction with other enforcement sanctions, however, the imposition of civil fines even in these cases can increase pressure on the facility to make fundamental financial or management changes. $^{23}$

In some states, civil penalty systems have performed to expectations; in others, state agencies have used available statutory fines rarely, if at all, ${ }^{2+}$ or have been plagued by enforcement problems. ${ }^{25}$ The statutory or regulatory design of a civil penalty system certainly contributes to the success or failure of the system, but equally important are the enforcement practices of the state agency. Two major elements are required for effective im. plementation of a civil penalty system: avoiding delay in the imposition of fines, and raising the price of repeated violations.

\section{Avoiding Delay in the Imposition of Fines}

The most deadly threat to effective implementation of a civil fine system is persistent, systemic delay. Delays in enforcement increase the costs of en forcement. Complex procedures require the state to monitor the continued existence or correction of violations and to assign surveyors and their supervisors as witnesses in several simultaneous proceedings. Lengthy suits consume legal services, a re source often scarce for a state agency.

As the cost of enforcement increases, the state agency may abandon certain fines because the payoff is too often seen as the amount of the fine at stake or the amount ultimately collected, which can range from $\$ 100$ to $\$ 500$ per case. Of course, this view of a contested fine is incomplete. Nursing home owners and operators have a more realistic view, as they more commonly recognize the broader costs of a citation. For example, even a citation for a relatively minor violation, incurring only a small fine, may increase penalties for later violations. This occurs if the violation is repeated and the fine is multiplied be. cause of the repetition, or if, even without explicit multiplication of fines, the agency levies greater fines in light of the facility's history. Civil fines have another, less financial effect; imposition of fines creates the penalties of adverse publicity and damage to the reputation of owners and operators as well as that of their facility. Finally, the continued use of civil fines has a deterrent effect. If the agency abandons enforcement of a large portion of contested fines or a class of fines, the agency decreases the risk that facilities assume when violating standards; thus it destroys the deterrent effect of the civil penalty system and rewards facilities that invest in contesting fines.

The impact of ineffective enforce ment on the regulated facilities paral. lels its impact on the regulators. Lengthy contests and agency abandonment of contested fines deter agency personnel from citing violations. Surveyors deal directly with an gry administrators during inspections and exit interviews without the cushion of time or representation, and surveyors typically have a continuing, if only intermittent, relationship with facilities in their assigned region. If sur- veyors perceive a pattern of nonenforcement, the normal response would be to avoid citations. ${ }^{26}$ Of the field staff interviewed in California, for example, each member reported "a number of experiences in which their issuance of a citation or of a condition level deficiency [report] was time-consuming, created an enormous amount of pressure on them, and in the end proved fruitless." ${ }^{27} 1 t$ is also the perception of consumer groups that many surveyors have left or "given up" due to frustrations with the process, including "enforcement actions initiated by them that are never settled because of the extended appeals process built in by stat. ute. . . ."28

The most substantial and costly delay in enforcement of fines occurs when a citation or assessment is appealed to a court. Judicial proceedings require a large investment of le gal services and may take two years or more from the time of filing to the time of the trial itself. ${ }^{29}$ A courtroom does not offer expertise in nursing home standards or regulation. While state agencies complain about judges who refuse to impose sanctions once a violation has been corrected even when the statute authorizes such a penalty, facility operators fear the emotional reaction of an anti-nursinghome jury to lists of deficiencies. It is more than coincidental that the most

For effective implementation, a civil penalty system must avoid delay in imposing fines and must raise the price of repeated violations.

enthusiastic supporters of civil penalty systems among state agencies report that they rarely, if ever, have a fine appealed to court.

Although access to judicial appeals should not be limited unreasonably, statutory or regulatory structures that actually encourage recourse to a court should be dismantled, while the system should provide full opportunities for review in administrative proceedings. The most ineffective procedural structure for enforcement of fines is that of Missouri, which provides that only a court can levy a fine. ${ }^{30}$ Not sur 
prisingly, statutory civil penalties apparently have not been used in Missouri.

An informal conference can be very valuable in giving the facility an opportunity to present any evidence mitigating the citation and fine and in

\section{Extensive use of the informal conference to forgive fines in favor of compliance can con- tribute to the perception of "paper corrections."}

allowing the agency to modify fines where appropriate. If a single highlevel administrator of the state agency conducts all informal conferences, as is reported done in Iowa and Florida, the process can contribute to consistency as well. Adjustments of fines at the informal conference can allow the agency to reward timely compliance by discounting the fine, a practice followed in several states. The modification, compromise or forgiveness of fines has a potentially harmful side effect, however, as it may "create an image of ineffective enforcement which can tend to anger the public, frustrate inspection, and encourage some facilities to file unfounded appeals and to drift in and out of compliance." 31 The state agency must recognize and deal with this effect directly if it is to retain the benefits of informal conferences.

Appeal bevond the informal confer ence to a full administrative hearing allows a more formal presentation of the facts by both sides and a review by an administrative judge or hearing officer not connected directly to the enforcement agency. This hearing must produce a record so that, if the administrative judge's decision is appealed, it may be judged on the record alone. The scope of review by a court over an administrative hearing is limited to whether the decision is supported by substantial evidence as presented in the record of the administrative hearing. This policy avoids duplication of efforts between the courts and the administrative system, utilizes the expertise of the agency, and contributes to the swift resolution of disputes.
To discourage appeal beyond the full administrative hearing, the fine should be payable at least by the time the result of the hearing is announced. Others have suggested additional methods for making judicial appeal less attractive. ${ }^{32}$

\section{Raising the Price of Repeat Violations}

State agencies and providers agree that the agencies should aggressively enforce regulations against the "bad guys" in the industry, those that consistently provide substandard care. Owners and administrators of nursing homes urge the removal of the worst offenders from business because these offenders harm all nursing homes in terms of increased regula. tion and poor reputation. A state agency that is effective in its sanctions against the worst facilities is likely to receive more support from the state's long-term care providers.

State agencies must maintain a steady level of enforcement and oversight over all facilities because the condition of facilities can change rap idly; however, more serious or habitual violators and facilities in serious decline warrant the closest attention. The inspection and enforcement process may be different with "problem facilities" than with facilities that only occasionally receive citations. A consultative approach to inspection and enforcement, in which the agency's primary goal is to encourage compliance, is unacceptable, and probably impossible in light of the adversarial nature of enforcement, with facilities with a pattern of violations or with serious violations.

Most statutes provide for amplified penalties against violations repeated within a particular time period, such as twelve months. If there is such an "expiration date" for repeated violations, the agency should establish a method of following at least the more serious violations in a facility even if an inspection is not regularly scheduled within that time period.

A continuing issue for the enforcement of standards against problem facilities is the perception that these facilities make "paper corrections" only and do not show actual improvement.
Most civil penalty systems allow a facility to avoid a fine for less serious violations if the facility corrects the deficiency or submits a plan of correction to the agency. ${ }^{33}$ While this provision is desirable in that it focuses on correction rather than penalty, it may be unjustifiable if the violations have been repetitive. An agency is without power to eliminate a period for correction if it is mandated by statute..$^{3+}$ Elimination of the period for correction in this situation requires that either the statute be revised or that the agency use the repet itive nature of the violation, in combination with other violations, to place the violation in a higher classification, one that does not allow time for cor rection.

Extensive use of the informal conference to forgive fines in favor of compliance can contribute to the perception of "paper corrections." For example, the Institute of Medicine case study on Connecticut reported that the state agency resolved every citation at the informal level and had yet to collect a fine. The study notes, however, that "[v]iewed from the perspective that compliance with the code is the division's goal, the division considers its civil fine system successful. The division is not able, however, to prevent facilities from continually slipping into and out of compliance under this system. Each violation is treated as a separate proceeding. ${ }^{35}$ This illustrates again the importance of special treatment for repeated violations or a pattern of vio lations. In addition, the agency should communicate the reasons for the modification or forgiveness of fines to the agency personnel who had cited the violations so that they can see that the agency is achieving its primary goal of compliance.

The state agency cannot effectively regulate problem facilities through these methods unless it has an effi cient information system that identifies facilities for special attention, that attracts to specific cases participation by supervisory personnel, and that notifies the agency of repeated violations, expiration of violations, and failures to correct deficiencies. The agency cannot adjust sanctions to the 
overall condition of the facility in comparison to other facilities unless the data for detailed comparison are available in a usable form. A paper file system organized by district and suborganized by facility is inadequate in all but the smallest states.

Because a major attraction of the civil fines is rapid enforcement, states must discourage delay by utilizing in formal conferences in a way that encourages consistency and does not demoralize staff. Some delay is unavoidable, and compromise of fines is generally desirable; however, it is essential that the agency inform field staff formally of the reasons for delay or compromise. The procedural struc ture of the system should not encour age appeals to the courts.

Civil fines are effective as deterrents only if they are enforced. This may require the agency to set clear priorities for enforcement among classes of violations or among facilities. Although this may be unattractive because it is an admission of the failure to enforce all regulations, it is better than creating the same policy de facto by abandoning certain groups of fines if challenged.

Repeated violations and patterns of violations should be treated differently from single violations. An efficient centralized information system is important in maximizing the effectiveness of civil fines, especially with regard to repetitive violations.

\section{The Under-Used Tool of Receivership}

That nursing home receiverships oc cur only infrecuently does not diminish their importance or effectiveness. ${ }^{36}$ Agency personnel experienced with receiverships report their effec tiveness both as a threat to facilities that have not responded to other sanctions and as a method to provide for the safe and humane transfer of residents from a facility that is closing. The capacity of the receivership to provide a legal framework for the improvement of substandard facilities, while fully documented in at least one case. ${ }^{3-}$ has not been adequately tested. The list of successful receiverships is growing: at least three facilities placed under receivership in New
York City are now operating under new ownership, with two owned by community groups; ${ }^{38}$ two receiverships in Michigan were successful in providing for safe transfer of residents, and in an interview, an agency chief reported, "We know it works." According to a Florida official, that state's experience has been the same. Most state agencies, however, remain unfamiliar with the implementation of

The receivership offers a powerful tool for the protection of the health and safety of nursing home residents.

a receivership, and this unfamiliarity may deter agencies from using a receivership even when it would be beneficial.

The infrequent use of receiverships is attributable to several other factors as well. First, the receivership is a severe sanction used only in more serious situations. Second, because it is generally inadvisable for the state agency to serve as receiver, private re ceivers should be utilized, but may be difficult to attract. Third, the cost of a receivership may exceed the income of the facility, due to the facility's poorly managed financial structure, predatory contractual arrangements, or costs associated peculiarly to the receivership, such as compensation for the receiver or special reporting requirements set by statute or by the court.

Statutory provisions, administrative practices, and effective use of the court's equitable power to fashion the receivership to meet the needs of the private receiver and other interested parties can increase the appropriate use of receiverships.

\section{Initiating the Receivership}

State receivership statutes typically allow the owner of the facility to peti tion the court voluntarily for the ap. pointment of a receiver. The coordi nated use of less drastic remedies may persuade the operator of a seri ously substandard home to petition for voluntary receivership. This avoids the problems of proving the specific, often narrow, statutory grounds warranting a receivership.

In the absence of voluntary petition by the owner, the state agency usually has authority to petition for receivership. Some statutes also explicitly permit a resident or his guardian to petition the court for receivership. ${ }^{39} \mathrm{Au}$ thority for a resident's petition is im. portant because the residents and their families are most likely to be familiar with the conditions in the facility and are most likely to suffer direct injury from substandard care. Giving the residents the capacity to petition the court directly for receivership also allows them to encourage the state to use this remedy. A New Jersey statute protects the owner from unsubstantiated suits by requiring the petitioner to show that the conditions have been brought to the owner's attention and that the owner has failed to remedy the situation within a reasonable period of time. ${ }^{40}$ The statute might also require a pre-litigation administrative process. These requirements protect the owner, and they do not create serious obstacles to legitimate challenges by residents in light of the severity of the receivership sanction. ${ }^{41}$

The grounds supporting the appointment of a receiver vary among the states. A statute that allows a receivership only when a license is revoked or denied is too narrow. ${ }^{42}$ Even if one accepts the underlying pre

\section{The state has a responsibility to enforce the protections in- cluded in the patients' bill of rights.}

sumption that receiverships are reserved for situations in which the continued existence of the facility is in jeopardy and the residents are in danger of precipitous transfer, this type of statutory provision prevents the use of the receivership in such situations as decertification and insolvency. Even though license revocation may even tually occur in these cases, the revo. cation process is so lengthy that the residents may suffer significant harm during that time.

The receivership also has the po- 
tential to redeem a facility for the marketplace by upgrading the quality of the facility. It is unlikely that this goal can be accomplished if the statute allows a receivership only when the facility has deteriorated to the point of closing

\section{Private Receivers}

The state agency has neither the staff nor the expertise to administer a facility. Because of its political nature, the agency is more subject to pressure from the public and from local politi cians to keep a facility open even when it is beyond improvement. For these reasons, the use of a private party as receiver is critical to the success of the receivership.

To some degree the reluctance of qualified private parties ${ }^{43}$ to undertake a receivership arises from fear of the unknown. According to interviews with state officials, Michigan has had two receiverships, both with private receivers who have offered to serve again. Detailed documentation of successful receiverships, especially from the receiver's perspective, is practically non-existent even though the experiences are transferable to other situations and could encourage the use of receiverships and the participation of private receivers, and could improve the receivership process.

In light of the delay that may be encountered in attracting a private re ceiver, the state should develop, and keep current, a list of parties willing and able to serve as receivers. The state agency in Florida, for example, maintains such a list and includes on the list retired nursing home operators. Of course, the most important tasks in attracting private parties to serve as receivers are to provide the resources the receivership needs and to define clearly the scope of the commitment of the receiver.

\section{Funding of Receiverships}

A private attorney for long-term care facilities has commented that "any state that is going to permit a receiver to be appointed is going to have to put its bank account behind [it]. ${ }^{14+}$ As discussed earlier, the financial re. quirements of the receivership may exceed the income of the facility. The most effective funding mechanism for filling the gap between income and expense is a revolving or set-aside fund designated for receiverships. The advantage of this type of fund is that it is easily and immediately accessible. The state of Florida has such a fund, and the state agency in Michigan is seeking such a fund in light of its positive experiences with receivership. Florida created its fund from a $25 \$$ per bed per year fee from each licensed facility. ${ }^{45}$

Absent a specially designated fund, counsel for the receiver should seek in the court's receivership order pro-

States should provide arbitra-
tion for the resolution of dis-
putes not resolved in internal
grievance procedures.

visions that bind the state agency to supplying the required financial resources. This could include expedited Medicare and Medicaid reimbursement, a temporary increase in reimbursement rate, or an advance on reimbursement to be recouped from the facility's assets at the termination of the receivership. Agreements be. tween the receiver and the state should be made a part of the court order itself so that they are easily enforceable.

If the purpose of the receivership is to transfer residents safely and to close the facility in an orderly fashion, the court should require the owner to post a bond against any possible deficits or give the receiver or the state a lien against the facility for the deficit. These payments by the facility are simply in fulfillment of the legal requirement in most state statutes that residents be transferred only in a planned manner

A private party may fear that service as a receiver of a substandard facility may become a trap from which he or she will never emerge. The receiver may be concerned about his or her personal reputation or that of his or her business. Moreover, the receiver reasonably would expect that residents, their families, and their friends would oppose closing the facility. These apprehensions all make service as a receiver unattractive; however, adequate planning for the receiver. ship can resolve these concerns.

\section{Controlling the Scope of the Receivership}

No matter what the purpose of the receivership, friends, family, residents, and interested community groups must be involved at the earliest stages. The state agency or the receiver should fully inform interested groups and individuals of the conditions leading to the receivership, the scope and term of the receivership or der, and the exact function of the receiver in this receivership, that is, whether the receiver is to transfer the patients or to maintain the facility for possible purchase. If the receiver has indicated that he or she will not consider becoming the permanent opera. tor of the facility, that should be com. municated clearly so that unreasonable expectations do not arise. One of the lessons learned from Michigan's first receivership and applied in its second receivership was the critical importance of involving relevant parties from the beginning and listening to what they said. This strategy avoided conflicts that occurred in the first receivership. Coordination with the community also was critical to the success of the Village Nursing Home receivership, in New York City, in which the facility was successfully upgraded. ${ }^{46}$

Honest and constant information to employees is also essential. ${ }^{4 ?}$ Fully informed employees are better able to assist in supporting the residents' needs. While the facility probably will be reducing employees over this period, it would be harmful if employees left en masse. In addition, employees who are hostile to the nursing home and under the stress of losing their jobs may displace this hostility and stress onto the residents. To avoid these problems, the receiver should develop a specific plan for relocation or job search assistance for the employees. The employees' unions, if any, should be considered parties interested in the receivership for purposes of information and plan ning.

All receiverships are ill-suited to long-term existence. If there is no 
plan for termination, however, it is likely that the receivership may ex tend beyond its optimum lifespan due to inertia or pressure from groups opposing closing the facility. Most nursing home receivership statutes estab lish some limit on the term of a re. ceivership. For example, the Florida statute provides for a 60 -day term, ${ }^{48}$ and the California statute, prior to recent revisions, provided three months. ${ }^{49}$ These terms are very short. If a receivership is to be effective, it must have sufficient time to operate. The court, through its equitable powers, has the authority to extend the expiration date in appropriate circumstances. ${ }^{50}$ The receiver should seek intermediate deadlines in the court order for the accomplishment of particular objectives. For example, if the purpose of the receivership is the transfer of the residents, the receiver and the state should have a concrete and detailed transfer plan in place at the inception of the receivership. Because the court has the duty to supervise the receivership, the receiver should use the court for assistance.

\section{Private Receivers and Personal Liability}

Potential private receivers justifiably are concerned about their personal liability for their actions as receivers. Some state receivership statutes provide that receivers shall not be liable except for gross negligence. ${ }^{51}$ If the statute does not so provide, counsel for the receiver should secure this provision in the court order. In addition, the court order should specifically state that attorney's fees attributable to the receiver's service shall be a necessary expense of the receivership and, therefore, chargeable as receivership expenses. The order should also include an appropriate provision on attorney's fees and state indemnification of the receiver for lawsuits against him or her arising from the receivership.

In summary, the receivership offers a powerful tool for the protection of the health and safety of nursing home residents. It often has proven effective in protecting the residents from injury due to precipitous transfer or drastic deterioration of care in a dying facility. The potential of the receivership for improvement of a facility has not been adequately tested, but thus far it has produced some success.

The receivership is a severe remedy and should be used only in cases in which the facility is in danger of closing, the health and safety of the residents are severely threatened, or there is a pattern of substantial and serious violations. In order to take full advantage of this tool, however, states must learn more about successful receiverships. The use of a private receiver is critical, and states must attract private receivers by providing sufficient financial support, preferably through special funds, and by defining the scope of the receiver's total commitment. While the proper legal framework for an effective receivership is established by statute and court order, the success of the receivership depends on concerted efforts outside the courtroom.

\section{Enforcement of Residents' Personal Rights}

The precarious psychological and physical condition of the typical nursing home patient and the absence of close friends or family for most residents require the state to take primary responsibility for protecting their health, safety, and welfare. This responsibility requires the state to enforce the protections included in the patients' bill of rights. Private litigation can supplement the state's efforts.

Private litigation to establish the liability of the facility to the resident for the facility's failure to comply with standards, including the patients' bill of rights, may compensate the resi. dent for injuries caused by the facility's actions. ${ }^{52}$ Such litigation, especially when accompanied by the availability of punitive damages, serves a regulatory function by empowering a private enforcer of state nursing home statutes. ${ }^{53}$ Several states have enacted statutory provisions creating private rights of action for nursing home residents. ${ }^{54}$ These statutes clarify the standing of the residents in litigation based on violations of state standards $s^{55}$ and provide statutory damages.
The statutes vary considerably in scope. For example, some statutes limit the statutory private right of action to violations of the patients' bill of rights ${ }^{56}$ while others provide a broader base. ${ }^{57}$ Some statutes provide

\section{Public participation is critical in ensuring quality care in nursing homes.}

for significant pre-litigation obstacles. The most extreme is that of Massachusetts, which requires that the suit be submitted to the medical malpractice tribunal. ${ }^{58}$ These hurdles were created in response to fears that the private right of action would spawn a multitude of suits. ${ }^{59}$ In fact, the private right of action has been used rarely. Any pre-litigation screening or filing requirement that takes a signifi cant amount of time is particularly burdensome to elderly nursing home residents with limited lifespans. These statutory obstacles are unnecessary and should be removed because formidable obstacles already exist: the residents' lack of access to attorneys, problems of proof associated with the residents' physical or mental state, the sheer length of litigation, and the fear of retaliation that arises from their total dependence on the institution even absent actual retaliation by the facility.

Provisions for statutory or punitive damages could offset these obstacles, however, if the damages are substantial. Reliance on actual damages suf. fered by the resident and proven in the customary way is inadequate for several reasons. ${ }^{60}$ First, elderly nurs ing home residents often pose signifi. cant problems in proving damages recognizable by law. Second, injuries are not often specifically attributable to violations of standards of care. It is difficolt to discover the cause of even physical injuries suffered by frail, el. derly clients. Third, violations of patients' rights, such as the right to privacy and the right to participate in medical decision making, rarely generate measurable physical damage. If the public enforcement nature of these suits is to be successful, recovery should include punitive or statutory damages that guarantee a mini- 
mum award. Punitive or statutory damages based on a multiple of actual damages obviously do not overcome the problem of relying solely on ac tual damages.

For all of these reasons, states should provide arbitration for the res. olution of disputes that are not re solved in internal grievance procedures. Legislation that requires that an arbitration clause be included in all admissions agreements would suffice. In order to encourage residents to use arbitration, the statute should provide, or require that the arbitration clause provide, the arbitrator with the authority to award damages. The damages provision should include a minimum award to overcome the prob. lems discussed above. The statutory arbitration clause could be narrowly drafted to cover violations of statutory residents' rights only, leaving other disputes to administrative procedures and the courts. The stature should establish both substantive and procedural rules governing the arbitration, including selection and qualifications of the arbitrator, ${ }^{61}$ the nature of the arbitration, and whether reasons are to be given for the decision. The facility should pay the arbitrator's fees, unless the grievance is entirely frivolous, an issue that itself should be arbitrable. Because the relationship of the parties is a long-term relationship and because litigation is unsatisfactory to all parties, the potential of arbitration in this context should be se riously studied, a task clearly beyond the scope of this article

Residents may also participate in the enforcement process under several state statutes that specifically allow residents to trigger enforcement provisions directly. For example, in at least six states, a resident and other appropriate persons have a right to petition for a receivership. ${ }^{62}$ Residents proceeding under consumer protection and other statutes have met with some success. ${ }^{63}$

Actions by the residents can be im portant both to the resident-litigants themselves and to the entire enforce ment process. These actions should be encouraged, where appropriate, because they can fill gaps in existing common law remedies ${ }^{6+}$ and because private actions can compensate the resident directly for the injury suffered. In fact, the federal system ought to provide specifically by regulation or statute for a private right of action for violation of at least some federal standards. The federal private

The most effective public participation is that which monitors and motivates the performance of both the facilities and the state enforcement agency.

right of action should include statutory minimum damages, punitive damages, and attorney's fees. A federal private right of action would give the federal courts jurisdiction over a claim and could encourage the development of a uniform law of patients' rights.

Because of the circumstances discussed above, that make litigation inaccessible to most residents, the state itself must enforce the patients' bill of rights. A few states have statutory fines specifically for violation of these provisions, ${ }^{65}$ although the success of these rights-specific fines is reported to be mixed. One state agency admin istrator reported that the same violations seem to recur, but that the fines probably do serve a deterrent effect. In 1982, the state of Georgia enacted substantial fines for rights violations, but the state administrative agency, believing that other methods are more effective, had not assessed fines within two years of the legislation. ${ }^{66}$ These statutes should include provi. sions for multiplying fines for re peated violations to create an incentive for states to place a priority on their enforcement.

Other states incorporate the rights provisions within the classification scheme. This may present a problem, however, if there is a perception that violations of the rights provisions do not threaten the health and safety of the residents. ${ }^{67}$ While it may be difficult to connect violations of some of the enumerated rights to health and safety, others, such as freedom from chemical and physical restraints, directly affect the health and safety of the residents. The appropriate ap proach to incorporating rights violations within classification schemes, when this is not specifically authorized by statute, is to focus on the legislative intent in drafting the statute. It would seem unlikely that a state legislature would adopt a patients' bill of rights within the statute and at the same time make it unenforceable by the state agency. Classification schemes that revolve around threats to the well-being or security of the residents rather than only the residents' health and safety have not posed this problem.

The enforceability of residents rights depends to some degree on the nature of the particular rights. Some, such as those focusing on medication, restraints, and funds, are as tangible and detectable as any other standard of care and should be enforced in the same way. Others, referring more generally to personal dignity, are more difficult to enforce in an adver sarial regulatory system. One study reports that "complaints of this sort may seem trivial when compared to reports of physical abuse or neglect ... but [they seem] to be a common problem for nursing home residents and . encourage feelings of isolation, helplessness, and depression. ${ }^{.68}$

In these situations, the participation of the public and the use of media tion and grievance procedures can be helpful. In a situation in which the relationship between the disputants continues beyond the dispute, such as in the nursing home context, mediation can be an effective method for resolving disputes. In 1980, the New York Office of Aging reported that about 60 percent of complaints received by ombudsmen were "resolved within the facility to the satisfaction of the patients." 69

A public monitor, provided for in several state statutes, is another important tool in the enforcement of residents' rights. Rights violations are not likely to occur during inspections and, therefore, are hidden from the view of the agency. The monitor provides a continuing official and public presence that can better detect and prove violations, instruct facility staff, and deter violations. 
The public monitor is a relatively inexpensive sanction. Because it harms no property right of the facility, no pre-sanction hearing is required The state of Georgia, which reports great success with public monitors, requires the facility to pay for the monitor. ${ }^{70}$ This then operates as both a fining mechanism and a monitoring mechanism. Although the facility must have an opportunity to contest that payment, the challenge should be reviewed concurrently with the place. ment of the monitor.

Frequent complaints of rights violations occurring in a particular facility support the placement of a public monitor to protect the residents and to identify the particular problem at the facility. Monitors could also be used in situations involving continuing, uncorrected violations and life. threatening violations of other standards.

\section{Public Participation}

Public participation is critical in ensuring quality care in nursing homes Because of the universal acceptance of this proposition, most revised state statutes have created conduits for public participation. These include public access to inspection results and other state-generated documents, public monitors, and public advisory commitrees. These provisions supple. ment the federally mandated ombuds man program.

A trend related to public participation in the quality assurance effort is the encouragement of consumerism among nursing home residents and their families. Mechanisms that facili tate public participation encourage consumerism as well, in that the mechanisms produce information upon which consumers can base decisions. Because information is the foundation of consumerism, several states have created ratings systems with the goal of communicating un complicated information on the quality of a particular facility to con sumers. Both public participation and consumerism have produced mixed results.

The most effective public participation is that which monitors and motivates the performance of both the fa- cilities and the state enforcement agency to ensure that each is fulfilling its duties. The California case study commented that, "with a tone that varies from the reasonable to the aggressively confrontational, these [advocacy] groups see themselves as being involved in an important battle between two powerful forces." ${ }^{71}$ Strong advocacy groups can balance out the pressure applied to state agency enforcement actions by state legislators and other public officials. The case studies on Texas and Georgia re ported instances in which the state agency received strong pressure against enforcement. In one case, media attention to these efforts has made it easier for the agency to resist. ${ }^{72}$ Several states, including Michigan, Florida, and New York, benefit from active participation of public interest groups focusing on long-term care. In each of these states, efforts by publicinterest groups have produced tangible results as reported by state agency personnel and outside evaluators in interviews with the author.

These groups all share attributes that contribute to their success. First, they are statewide or local organizations that become familiar to and with the state's agencies and long-term care facilities. They are organized or "institutionalized," have access to the media, and have developed expertise in long-term care issues. Second, they have guaranteed access to the facilities and to relevant documents generated by or filed with the state agency. Third, they have identified advocacy of the viewpoint of nursing home residents as their primary goal, and, because they are independent of both the state agency and the facilities, they are able to carry out that goal.

The institutionalization of these public interest organizations allows them to operate more effectively than individual members of the general public. The benefits of such an orga nization include long term participa tion in the process, familiarity to and with the major actors, and the development of expertise. These benefits all allow the organization effective and efficient access to the process, especially in crisis situations. ${ }^{73}$
Characteristically, community efforts, other than those that are highly organized or are joined to a stable structure such as that provided by these groups, are often dispersed and ineffective. Reliance on volunteers and difficulties in communicating and translating complex issues into shortterm goals contribute to the ineffectiveness of non-institutionalized groups.

State statutes and administrative policies should guarantee effective access of these groups to the facilities and to the state's records. If access can be barred by facilities, advocates would hesitate to pursue complaints for fear of losing access entirely. Facilities under pressure would be the first to bar access. The state of Michigan, for example, has a procedure for "certifying" public interest organizations for access to facilities. ${ }^{7+}$ The ad. vantage of this method is that it re. moves from the facility the burden of investigating organizations or of ad. mitting all such organizations. Of course, such a certification procedure may be implemented unfairly or used by the state agency to protect itself from particular groups. Access to patient records is more controversial. While some statutes specificially allow such access, even some directors of ombudsmen programs oppose access to patient records. ${ }^{75}$

Access to inspection results or re ports and to records of sanctions or

\section{Several defects in the applica- tion of market analysis to nursing home care undermine a reliance on consumerism.}

deficiencies is typically guaranteed to the public in general by the state's nursing home statute or the state's ad ministrative procedures act. ${ }^{76}$ To be effective, access to the information must be available in a timely manner and must not be delayed beyond the point of relevance. ${ }^{\top 7}$

While there certainly is room for mediation and the non-adversarial resolution of disputes in the nursing home context, advocacy and adversariness are facts of life in nursing home regulation. The advocacy of the facili- 
ties and the state agency must be balanced by advocacy on behalf of the residents. In enforcement, the state agency and the facilities should not lose sight of the fact that there are three, not two, parties in interest. Furthermore, effective advocacy of the interests of the residents can be critical in the successful implementation of such sanctions as the receivership. Groups identifying themselves as mediators between the facility and the residents make an important contribution to the resolution of disputes, but a mediator cannot serve as an advocate, and advocacy is a required element in an effective regulatory process.

Several agency administrators interviewed by the author noted that more general public pressure, as is generated by newspaper coverage, is helpful. In fact, one commented that "the newspapers ought to do more." Most state agencies do not actively seek coverage of conditions in long-term care or enforcement of standards. New York's experience in the use of monthly press releases reveals one reason that agencies hesitate to actively involve the press. This practice was ended within a year because the health department was inconsistent in its description of facilities and lacked confidence in the results, and be cause the releases caused friction between the department and the facilities. Reportedly, an operator complained to the department "that his fa cility had been lumped with what he regarded as really lousy places." ${ }^{-8}$ The power of exposure of deficiencies should not be discounted, however, and should be accounted for in the implementation of sanctions.

\section{Consumerism}

The rationale supporting consumer ism as a supplementary regulatory scheme is that market forces will operate to drive providers of poor care from the market and reward providers of good care. There are several de fects in the application of market analysis to nursing home care, however, that undermine a reliance on consumerism.

First, consumerism depends on the existence of consumer choice. In the case of nursing home care, this choice may not exist, or may exist but with little or no reference to quality. A potential nursing home resident or the resident's family may have little or no choice among facilities once the essential factors of source of pay (if public pay) and level of care are applied to produce the group of facilities that are actually available to the resident. In addition, when location is factored in, to allow the contact with family and friends that will contribute to the health of the resident, the ac-

\section{Suspension of admissions works well because it com- bines a de facto fine with ad- verse publicity.}

ceptable group narrows even more. The capacity for choice is limited also by the length of time available for re search and the stress accompanying the placement. Market failure in the nursing home context is multiplied because the resident or potential resi dent, the actual consumer, is often not the one choosing or paying for the service. ${ }^{79}$

Second, nursing homes do not operate in a competitive market. Access to the nursing home market is restricted by certificate of need (CON) requirements. Although many health planning agencies have concluded that there is an excess of nursing home beds, state nursing home enforcement agencies are still hampered in enforcement actions by a shortage of beds. ${ }^{80}$ In an article in the New England Journal of Medicine, Nicholas Rango, M.D., is sharply critical of CON requirements as applied to nursing homes and echoes complaints made by persons active in long-term care as regulators, providers, advocates, or consumers. Dr. Rango criticizes CON as creating a situation of "stable excess demand" in which "privately paying consumers obtain all the nursing home care they desire" and a "low-income and severely dependent person finds himself in a state of double jeopardy." ${ }^{81}$ He goes on to state that "fiscal policies aimed at restricting the total supply of nursing-home beds tend to render spurious the government's own efforts at quality assurance." 82

Although a full discussion of the non-competitive nursing home market is beyond the scope of this article, its impact on consumerism and on public regulation warrants some attention. First, the policies of health planning agencies should reflect the "sub-markets" within the general nursing home supply that exist in reference to source of pay, level of care, and a realistic view of geographic location. Second, enforcement agencies should participate in CON proceedings by submitting the facility operator's full record, and the health plan. ning agency should be required to re. view the full record. An efficient in. formation system could produce the relevant information in usable form. Finally, if a CON is required for purchases, it should be waived for facilities to be purchased or expanded under new ownership after receivership. This would encourage improvement of substandard facilities.

Despite these factors, consumerism does have an impact on the regulation of nursing homes. Competition for the more desirable residents, typically private-pay residents requiring little supportive care, does require that facilities guard their reputations.

Public disclosure of inspection results, reports, and sanctions encourages consumerism. If a statute incorporates a bias toward publication, a classification scheme for violations would prove especially helpful. Such a scheme would maximize information that enables the public to weigh the severity of violations and would minimize damage to facilities with only temporary or minor deficiencies. (Public-interest groups with experience and expertise in the inspection process generally would not need this assistance in understanding the mean. ing of the documents, of course.) Re quired publication of deficiencies could be effectively geared to the severity of the violations. In cases of $\mathrm{mi}$ nor deficiencies that are not repetitive and not part of a pattern of violations, publication could be a point of negotiation between the state agency and the facility to encourage speedy rem. 
edy of minor violations and could eliminate a prime motivation for timeand resource-consuming contests of minor violations. Publication of cita tions in local newspapers, whether at the initiative of the newspaper or the agency, can increase the deterrent ef-

The federal government owes the taxpayers an acceptable level of supervision of the quality of the product received for its nursing home expenditures.

fect and the de facto penalty involved in a civil fine case.

State documents on ratings, whether inspection reports and re sults or special reports, could promote consumerism, but they are complex and are inaccessible on a practical basis to most individuals, due to the time constraints involved in choosing a facility. At least five states have developed statutory ratings systems to produce information for con sumers that is both simple and useful. ${ }^{3.3}$ While a rating is simple to understand, it may attempt to achieve the impossible if it purports to summarize accurately in one letter grade too many disparate elements. In addition, the condition of a facility may change rapidly, while a rating depends on the slow and intermittent process of inspection and evaluation. Finally, the ratings systems have attracted more than their share of litigation. ${ }^{\text {th }}$ The comprehensive, and perhaps subjective, nature of the rating makes the rating difficult to review and easy to overturn. ${ }^{85}$ This may cause the agency to fear review and encourage the facility to litigate because of the perceived market value of the rating.

The states' experience with ratings systems has been mixed. Some deem the ratings worthless, while others are more supportive. A study of New York's rating system commented that "no one expressed much confidence in the ratings as a tool for consumers There were too many inconsistencies across regions. Eighty-eight percent of the nursing homes in 1978 were clustered in the 'good-state' category
... No effort was made to develop a consumer handbook listing the ratings . . . ${ }^{86}$ Florida's ratings system, ${ }^{87}$ though struggling with the issue of subjectivity, has some attributes worth emulating: it is a three-tiered system (superior, standard, and conditional); only twenty percent of the facilities in the state are rated superior; and use of the ratings in advertising is controlled so that the advertising does not out. last the rating.

\section{Suspension of Admissions}

When the authority to suspend admissions is provided under the state's licensing power, the state has the power to suspend all admissions, not only admissions of residents receiving public benefits for nursing home care.$^{88}$ Suspension of admissions is a serious sanction, but it need not be limited only to situations in which there is an immediate and serious threat to the health and safety of the residents. In fact, if there is such an immediate threat, suspension of ad. missions should be used in conjunc. tion with other remedies, such as public monitors and receiverships, that more directly protect the safety of the current residents of the facility. Suspension of admissions could be used effectively in situations of habit ual, significant violations. The state of Georgia has relied on suspension of admissions and monitors for residents' rights violations rather than using the fines provided for by statute. ${ }^{89}$

Suspension works well because it combines a de facto fine with adverse publicity, and it prevents new residents from "settling in" at the facility. Except in truly life-threatening situations, allowing current residents to re main in the facility recognizes that the injury of substandard care may be outweighed by the injury of being uprooted and transferred. The financial impact of a total suspension is significant, of course, but its economic impact is small at the beginning and is cumulative over time. While attrition at a long-term care facility occurs at a significant pace, it is not so rapid that a suspension immediately bankrupts the facility; rather, the financial penalty of a suspension multiplies over time. Most suspensions last a very short time. A state agency administra tor in Florida reported that in his experience the typical suspension lasts 30 days. Suspension of admis sions is properly an emergency power effective without a prior hearing under certain circumstances.

\section{The Role of the Federal Government}

Although there is certainly argument over the appropriate scope of the role of the federal government in regulating long-term care, the assurance of quality care and enforcement of sanctions cannot be controlled solely by the states. The federal government owes the taxpayers an acceptable level of supervision of the quality of the product received for its nursing home expenditures. Further, when health care is paid for by a third party (as in the case of Medicare/Medicaid), the ability of the consumer to monitor effectively the quality and quantity of the health care to which he is entitled, is minimized. The federal government, as a third-party payor, must aggressively monitor and enforce quality and quantity requirements. Federal participation in enforcement prior to decertification also allows a coordinated approach between federal and state governments. Finally, states are subject to political pressures by local legislators, judges, and other groups, and state budgets are vulnerable to political hatcheting.

The analysis presented previously of the states' experiences in using the intermediate sanctions over the past decade produces several particular suggestions for a federal role in enforcement.

\section{State-Federal Uniform Information System}

The inadequacy of most intra-state information systems has obstructed enforcement efforts. Repeatedly, state agencies, evaluators, and the public have decried the unavailability of es sential data on long-term care facilities and the surveillance and enforce. ment actions of individual states. For example, the use of waivers was a concern of a legislative commission 
in Illinois, but when the commission asked whether the Department of Health kept a file of waivers, it was told that "for five or six months they had been filing the new and renewed waivers that came through the Division, but . . . waivers approved by regional personnel were scattered throughout the homes' files." 90 The case study on California noted that "major areas of concern expressed by consumer advocates during public hearings and legislative meetings include the unavailability of complete and accurate information about nursing homes." 91 This complaint echoes the experience of evaluators of California's system. The multiplication of fines for repeated violations was of concern to a state commission in California, but the Licensure and Certification Division (LCD) had no data on repeated violations even though it had authority to levy treble fines. ${ }^{92}$ At least as of August 1983, the headquarters of LCD did not even re view decisions made at the informal conference level where most fines were resolved. ${ }^{93}$

A paper system that relies on file folders organized by facility is inade quate for the complex enforcement process and robs the intermediate sanctions of their effectiveness. Cumulative agency statistics that count the number of times a sanction has been used are also insufficient.

The previous analysis has identified several instances in which an efficient information system that produces usable information would assist state efforts. A computerized information system that produces usable data would encourage efforts to monitor the surveillance process for consistency, to punish the repeat offenders, and to give the public the information needed for advocacy and consumerism. A statistical audit of citations and sanctions correlated with relevant data on the facilities involved would assist the states in achieving consistency in the enforcement process. An effective information system is essential for aggressively penalizing repeated violations, especially for the identification of the expiration dates of violations. To the extent that public disclosure and reliance on the market are desirable supplementary tools, they can only exist if there is accurate and current information on facilities. A centralized reporting system for complaints that would record complaints and their outcome is increas ingly more important.

The information system should be federally supported financially and should be uniform among the states. The system would increase the efficiency of the state process and would not involve the federal government in any higher degree of regulation.

The uniform information system would produce substantial interstate benefits as well. It can be utilized in analyzing successful enforcement strategies, in identifying enforcement errors, and in better training surveyors and attorneys general. Interstate data permits more effective and efficient regulation of interstate multifacility long-term care corporations. It would also make possible control over substandard administrators or operators who cross state lines to operate other facilities. Many provider associations press for uniformity or consistency among the states, yet the data system necessary for evaluation of consist ency in enforcement either within states or across state lines does not yet exist.

\section{Oversight of State Enforcement}

If the federal government is to over come some of the current deficiencies of state enforcement, it must be a sufficiently powerful counterforce to the pressures placed upon state government. To be an effective counterforce, the federal government must develop measures to assess the state's performance.

The lack of communication between the federal and state government is illustrated in the report of an Illinois legislative commission. An administrator of the Department of Health stated to the commission that "I see the whole key to the uniformity issue as providing enhanced training" but he also said that " $[\mathrm{m}]$ any of the training activities in the past had to be cancelled due to the fact that it was more important to get the survey done than it was to train the surveyors. This had partially contributed to somewhat of a lack of uniformity among the survey staff." Finally, the Illinois commission's report notes that " $[w]$ hile Illinois' training was dis appearing, the federal government was assuming that state training was increasing . . . federal training shrank from six weeks to one week, leaving the states to pick up the difference." ${ }^{94}$

The effectiveness of federal pressure is also illustrated in Illinois, where the loss of $\$ 2.2$ million of fed. eral money caused the Illinois Bureau of the Budget to increase the Department of Public Health budget to add forty surveyors. ${ }^{95}$ To be more effective in supervising the states, the federal government should use intermediate sanctions, ${ }^{96}$ such as a discount in federal contributions or federal monitors for use against the states themselves regarding the performance of their contract with the federal government.

Finally, flexible enforcement sanctions cannot be used effectively without sufficient staff for surveys, admin. istrative procedures, adjudication, and follow-up. Sufficient staff requires a supplementation, not a decrease, of the budget.

\section{Federally Mandated Intermediate Sanctions}

Intermediate sanctions clearly enhance the capacity of the states to en. force nursing home standards. While most states have enacted statutes providing for certain intermediate sanctions, some states either do not have available the more effective sanctions or have statutes that include serious defects that hinder their effectiveness. In these states, legislative reform should be a priority. To further this goal, the federal government could mandate the enactment of intermedi. ate sanctions by the states.

Of course, there are disadvantages to a federal mandate, including resistance'by state legislatures to federal "interference." More important, the previous discussion of the states' experience with intermediate sanctions shows that there is often a wide gap between the availability of particular sanctions and the actual use of these sanctions by the state agencies. If a federal mandate is to be worth the effort, it must confront and resolve 
these problems.

While there may be many reasons underlying a state agency's failure to use available intermediate sanctions, including unfamiliarity with the sanctions and the unavailability of essential information, two major reasons are budget limitations and structural defects in the sanctions. The implementation of intermediate sanctions is costly; enforcement is more expensive than non-enforcement.

If the federal government mandates particular intermediate sanctions, federal financial support should be provided for the special implementation requirements of the mandated sanctions. This federal support may also serve as a "carrot" that could diminish resistance by the state legislatures. Any federal mandate of sanctions should include design specifications that build on evaluation of the experience of states that have used the particular sanctions. For example, if civil fines are mandated, administrative assessment of fines, appropriate penal. ties for repeated violations, and monitoring of citations and informal reso. lutions for consistency should be among the required provisions. The federal government, however, should not require a uniform statute, for in most situations there is room for successful variations.

The necessity of financial support, the attention to structural detail, and the resistance of state legislatures support a recommendation that the fecleral government be selective in mandating sanctions. Because the civil fine systems have received consistently positive evaluations, this sanction is very attractive for federal mandate. In addition, more than a third of the states do not have authority for civil fines. Successful imple. mentation does require an investment on the part of the agency, and federal financial assistance will be critical. A second sanction that has proven very successful is the suspension of admissions pursuant to the state's licensing authority, as discussed previously

Although several other sanctions are worthy of consideration for mandate, state agencies must set priorities among sanctions so that available sanctions are used effectively. As dis- cussed in the context of delay in the enforcement of fines, ineffective implementation damages the enforcement mechanism.

\section{Conclusion}

The previous decade witnessed a reform in state nursing home legislation that was revolutionary in its development of innovative methods for enforcement of standards of quality. Advocates of strict enforcement of standards began to realize that strict enforcement is best accomplished by "making the punishment fit the crime." Clearly, the goals of nursing home regulation are not entirely punitive, but include rehabilitation and deterrence as well, and the intermediate sanctions present the best hope for meeting each of these goals. States that have not enacted the more successful intermediate sanctions discussed in this article should make legislation a priority. Legislation, however, is only the first step; implementation remains the biggest challenge.

It is unfortunate that, just as state agencies were handed a variety of enforcement tools that necessarily required more training, more data, and more attention for successful correlation with violations of standards, state enforcement budgets were reduced. Even with the budgetary problems, the states' experiences in implementing the intermediate sanctions reveal the need for legislative revisions in some cases and for changes in administrative practices in others. Finally, although the states have taken the lead in nursing home regulation and enforcement over the last decade, evaluation of the performance of several states indicates a continuing need for federal involvement.

\section{References}

1. As of 1980 , nearly all states had re vised their nursing home licensing statute to add intermediate sanctions. ABA СОМ. mission on legal Problems of the Elderly MODEL ReCOMMENDATIONS: IN'TERMEDIATE SANCTIONS FOR ENFORCEMENT OF QUAIITY Care in Nursing Homes (American Bar Ass'n, Washington, D.C.) (1981) at 3 [here inafter referred to as MODEL RECOMMENDA. TIONs]. A thorough analysis of several intermediate sanctions is presented in Butler, P.A., Nursing Home Quality' of Care En. forcement, Part II-State Agency' Enforce ment Remedies, Clearinghouse Review 14(7): 665-701 (October 1980).

2. For a complete discussion of transfer trauma resulting from involuntary transfer of elderly patients, see Comment, Involuntan' Relocation of Nursing Home Residents and Transfer Trauma, SAINT LOUIS UNIVERSITY LAW JOURNAL 24(4): 758 (March 1981)

3. Although many health planning agencies have concluded that there is no short age of nursing home beds, a shortage still exists when supply is adjusted by level of care, source of pay and location. More im. portantly, state agencies enforcing nursing home standards believe there is a shortage in most states and adjust their enforcement techniques in light of the perceived shortage.

4. A substantial body of criticism directed at license revocation is concerned with delays in effectuating the revocation. Once a state administrative agency revokes the operating license of a facility, the facility has the opportunity to pursue administrative appeals and then seek judicial review. During this time, revocation is stayed and the facility continues to oper ate. A 1973 report by the California Deputy Attorney General indicates that license revocation in that state had been taking as long as five and seven years. Cohen, Long Term Care: A Challenge to Concerted Legal Techniques, OHo UNIVERSITY LAw Re. vlew 2: 642, 667 (1975). The Connecticut state agency has imposed the revocation sanction only once in the past four years. That process consumed two years. Institute of Medicine, Case Study of Connecticut (Draft) at p. 20.

5. The Institute of Medicine project staff conducted case studies of the implementation of intermediate sanctions in the states of California, Connecticut, Georgia, and Texas. It also conducted public hearings on nursing home regulation. The au. thor personally interviewed state agency administrators from five additional states not covered by the case stuclies and re viewed previously published case studies and legislative reports of other states. Footnotes in this article refer to drafts of the Institute case studies; final versions were not available at the time of the research.

6. See S. JohnSon, N.P. TERry, M WolfF, Nursing Homes and the Law: State Regulation and Private litigation (Harrison Cew, Norcross, Ga.) (full discussion of litigation involving a wide range of challenges to state enforcement of nursing home standards)

7. Most disputes involving state nursing home statutes occur in state administrative proceedings or in the lower state courts that infrequently report written opinions. Because the state statutes are similar, however, case law developed in one state is relevant to most others. When considered rogether, the reported cases, though few in number, form a coherent body of law. 
8. Although state nursing home licen sing statutes have been challenged as ex ceeding the state's police power, these challenges consistently have failed. See, e.g., Hoffman v. Moore, 420 N.Y.S. $2 \mathrm{~d} 771$ (N.Y. App. Div. 1979); Eagleton v. Patrick, 370 S.W.2d 254 (Mo. 1963)

9. See, e.g., Volunteers of America Care Facilities v. Village of Brown Deer, 294

N.W. 2d 44 (Wis. App. 1980)

10. See, e.g., Levine v. Whalen, 349 N.E.2d. 820 (N.Y. 1976).

11. Melbourne Corp. v. Hearing Board for Nursing Homes, 302 N.E.2d 729 (IIl. App. 1973), aff'd, 322 N.E.2d 481 (III. 1974 ).

12. Levine v. Whalen, supra note 10 , at $824-25$.

13. See Melbourne Corp. v. Hearing Board for Nursing Homes, 302 N.E.2d 729 (Ill. App. 1973). In High Ridge Mgmt. Corp. v. State, 354 So.2d 377 (Fla. 1977), the Supreme Court of Florida found Flori da's five-tier rating scheme an unconstitutional delegation of power because the statute provided objective criteria for only one of the five possible ratings. The result in the case had no impact on the rating system as the legislature had redrafted the system to make it more specific prior to the court's decision. This may explain, in part, the court's result.

14. See, e.g., Lackner v. St. Joseph Con valescent Hosp. Inc., 165 Cal. Rptr. 198, 203-04 (Cal. App. 1980).

15. ILLINOIS LEGISLATIVE INVESTIGATING COMMISSION, REgULATION AND FUNDING OF ILLINOIS NURSING HOMES (1984) at 15

16. Id. at 17

17. The American College of Health Care Administrators presented statistical evidence at the Institute of Medicine hear ings that indicated significant differences in rates of citations among states. The Cali fornia case study reported that both the California Association of Homes for the Aged (CAHA) and California Association of Health Facilities (CAHF) complained of unfair variation among surveyors and the Licensing and Certification Division (LCD) districts. The CAHA is an organization of nonprofit providers. The CAHF is an asso ciation of proprietary long-term care facili ties. The California case study noted that these complaints are "commonly given by providers." Institute of Medicine, Case Study of California (Draft) at 46

18. See, e.g., IOWA CODE ANN. \$I35C.36 (West I985) which served as a model for Mo. Rev. Stat. \$198.085.I (1983). As of 1980 , ten states' statutes provided for the classification of violations. See MODF. REC OMMENDATIONS, SUpra note 1

19. Ore. Rev. Stat. $\$ 41.715$ (1983) provides: "After a public hearing the Assistant Director for Health by rule shall adopt a schedule establishing the civil penalty that may be imposed. ..." The As sistant Director is limited, however, to a maximum of $\$ 500$ for each violation.

20. See, e.g., Cal. Health \& Safety Code $\$ 1424$ (West 1979) (a Class A viola- tion is one highly likely to threaten death or serious injury to residents; a Class B violation is one that nevertheless seriously affects the welfare of residents). See also IlL. ANN. STAT, ch. 1111/2, $\$ \$ 4151-129$ to 4151-131 (providing for Class A and Class $B$ violations similar to those in California, as well as Class $C$ violations which are those indirectly threatening the welfare of residents)

21. The state agency in Iowa has devel oped a "nine factor form" that is used in assessing the amount of the penalty. The nine factors used are:

1) Period of time over which the violation occurred;

2) The frequency of the violation;

3) The facility's history with this type of violation;

4) The facility's intent or reason for the violation:

5) The effect, if any, of the violation on the health, safety or security of residents;

6) Whether other violations, in com bination with the violation at issue, caused increased harm or adverse effects to the residents of the facil. ity;

7) Facility follow up after the violations, that is, whether corrective measures were implemented;

8) Accuracy and extent of facility records in regard to the violation and their availability to the Depart ment;

9) The number of additional related violations occurring within the same short time span as the violation in question. See, Iowa Rules and Regulations Setting Minimum Standards for Health Care Facilities Rule 56.9( I 35C)

The benefits of this form were favorably noted in COMMISSION ON CALIFORNIA STATE Government Organization and ECONOMY, The Bureaucracy of Care: Continuing Policy Issues for Nursing Home Services AND REGULATION (1983) at 125 hereinafter referred to as BuREAUCRACY OF CARE].

22. Iowa and Florida, among other states, rely extensively on the informal conference for resolution of fines and actually do collect fines through them without recourse to the courts. California had developed a "traffic citation" method by which the facility can pay the minimum fine for the class of violation rather than contesting the violation and risking a higher fine. Cal. Health \& Safety Code $\$ 1428$ (b) (1979). The constitutionality of this provision was aggressively litigated and has been upheld. Lackner v. Perkins, 154 Cal. Rptr. 138 (Cal. App. 1979). See also Lackner v. St. Joseph Convalescent Hosp., 165 Cal. Rptr. 198 (Cal. App. 1980) Myers v. Astoria Convalescent Hosp., 164 Cal. Rptr. 495 (Cal. App. 1980). In 1984, the California legislature repealed the "traffic citation" system. Cal. Health \& SAFETY CODE $\$ 1428$ (Supp. 1985).

23. Johnson, S., Nursing Home Receit- erships: Design and Implementation, SAINT LOUIS UNIVERSITY LAW JOURNAL 24(4): 681, 700 (March 1981) [hereinafter referred to as Nursing Home Receiverships]

24. For example, as of Spring 1984, the Illinois agency had not begun active use of the civil penalty system that had been authorized by statute in 1980 . This hesitancy to use fines has been attributed to the lack of legal staff. REgulation AND Funding of IlLiNOIS NURSING HOMES, supra note 15 at 97-98.

25. The enforcement problems in California are detailed in BUREAUCRACY of CARE, supra note 21 , at 112-31

26. See generally Christianson, J.B. Long-Term Care Siandards: Enforcement and Compliance, Journal of Health POLI TICS, POLICY, AND LAW 4(3): 414 (Fall 1979)

27. Case Study of California, supra note 17 , at $48-49$

28. Id. at 45 .

29. "Although the statute stresses the need for speedy resolution in . . . court, speed is hardly the hallmark of these cases. In Los Angeles County ... in the first three months of 1983 citations dating back to 1980 and earlier were at various stages of the court process. . ." Bureauc RACY OF CARE, supra note 21, at 155

30. Mo. Ann. Stat. $\$ 198.067(2)$ (Vernon Supp. 1984).

31. Bureaucracy of Care, supra note 21, at 138 .

32. See Model Recommendations, supra note 1 , at 12 .

33. See, e.g., Ore. Rev. Stat

$\$ 441.710(2)(1983)$.

34. See previous discussion of procedural requirements. See Aurelia Osborn Fox Memorial Hosp. Soc'y v. Whalen, 391 N.Y.S.2d 20 (N.Y. App. Div. 1977)

35. Case Study of Connecticut, supra note 14 , at 19 .

36. As of 1981 , when the receivership was a very new sanction, at least three dozen receiverships had taken place. Jost, T., Intermediate Sanctions, in LONG.TERM Care and THE Law (Johnson ed.) (National Law Publishing Co., Owings Mills, Md.) (1983) at 325.

37. Nursing Home Receiverships, supra note 23, at 693-705. The Cobble Hill Nursing Home in Brooklyn is also reported as upgraded during a receivership and then purchased by a community group. Doty, P., Sullivan, E.H., Community Involvement in Combating Abuse, Neglect, and Mis treatment in Nursing Homes, MILBANK MF MORIAL FUND QUARTERLY/HEALTH AND SOCI ETY 61(2): 222, 234 (Spring 1983). Most states, however, have not used the receiv ership for this purpose

38. Id.

39. See, e.g., Mo. Ann. Stat. $\$ 198.099$

(Vernon Supp. 1984); N.J. STAT. ANN.

$\$ 26: 2 \mathrm{H}-38$ (West Supp. 1984-85).

40. N.J. STAT. ANN. $\$ 26: 2$ H-39(b) (West Supp. 1984-85)

41. See JOHnson, Terry \& WOlF, supra note $6, \$ 1-23(1985)$ 
42. See, e.g., N.Y. Pub. Health Law $\$ 2810$ (2(a)) (Consol. 1984).

43. Prior to recent revisions, the Califor nia receivership statute required that a re ceiver be a licensed nursing home admin istrator. Cal. Health \& Safety Code $\$ 1327$ (West. Supp. 1984). The state was unable to get qualified private receivers for the receiverships it attempted. The CAHA (nonprofit facilities) has now supplied the state with a list of receivers. Further, the legislature has amended the statutes to al low as receiver any" "responsible person or entity, as determined by the court." CAL. Health \& SafeTy Code $\$ 1327$ (West Supp. 1985).

44. Long Term Care and the law, (J.W. Skiba, ed.) (Pane] Publishers, Greenvale,

N.Y.) (1979) at 209

45. Fla. STAT. ANN. $\$ \$ 400.062(3)$,

400.063(1) (West Supp. 1985).

46. Nursing Home Receilersbips, supra note 23 , at 705-12.

47. $I d$ at 697

48. Fia. Stat. AnN. $\$+00.126(2)$ (West Supp. 1985).

49. See Cal. Health \& Safety Code $\$ 1331$ (a) (West Supp. 1985) (changing the receivership term to six months).

50. Even if the statute restricts the abil ity of the court to renew the term, the court has a residual power to appoint a common law equitable receiver and should be encouraged to do so. Of course, the statute itself may authorize an exten sion. See, e.g., Cal. Heal.th \& Safety Code $\$ 1331(a)(1)$ (West Supp. 1985).

51. Equitable receivership derives from the common law power of courts of equity. Courts under this power appoint re ceivers to maintain and conserve property and assets. In preserving the property and assets the receiver owes a duty of ordinary care. Vander Vorste v. Northwestern Nat'i Bank, 138 N.W.2d 411 (S.D. I965); see also Annot., 20 A.L.R.3d 967 (1968). Eight states that provide for nursing home receivership by statute specifically provide that the receiver is personally liable for gross negligence only. Cal. Health \& SAFETy CODE $\$ 1328$ (West 1985); Fla. STAT ANN. $\$ 400.126(7)$ (West 1985); ILL. ANN. STAT. ch. $111 \frac{1}{2}, \$ 4153-513(\mathrm{~b})$ (Smith-Hurd 1985); ME. REv. STAT. ANN. tit. 22, $\$ 7936$ (1984); MinN. STAT. ANN. $144 A .15(4)$ (West 1985); N.Y. PuB. HEALTH LAW $\$ 2810$ (d) (McKinney 1977); OKLA. STAT. AnN tit. 63, $\$ 1-1935$ (A) (West 1984); WIS STAT. ANN. $\$ 50.05$ (12)(b) (West 1984-85).

52. See generally JoHnson, TERry \& WolfF, supra note 6 , chs. $3,+$ and 5 .

53. The most comprehensive analysis of private litigation across a broad range of legal theories is presented in, Butler, P.A., Nursing Home Quality of Care Euforcement, Part I-Litigation by. Private Par. ties. CieARINGHOLSE RFyieW $1+(7): 622$ (October 1980)

5t. See, e.g., N.Y. Pub. Health Law $\$ 2801(\mathrm{~d})$ (Consol. Supp. 1980); W. VA CODE $\$ 16-5 \mathrm{c}-15(\mathrm{c})(1977)$; N.J. STAT. ANN $\$ 30: 13-8$ (West Supp). 198t-85)
55. See Vossmeyer, S., Felix, D., The Missouri Omnibus Nursing Home Act of 1979: A Legislative History; SAINT LOUIS UNIVERSITY LAW JOURNAL 24(4): 617 (March 1981 ).

56. See, e.g. OKla. Stat. Ann, tit. 63 $\$ 1-1918 \mathrm{~F}$ (West 1984)

57. For an overview of statutory private rights of actions in Missouri, see Hoffman A.B., Schreier, K.E., A Private Rigbt of Action Under Missouri's Omnibus Nursing House Act, Saint Louls UnJversity LaW JOURNAL 24(4): 661, 665-67 (March 1981)

58. Mass. Gen. Laws. AnN. ch. 111, $\$ 70 E$ (West 1983).

59. See Vossmeyer \& Felix, supra note 55 , at 644

60. See generally JOHNSON, TeRRY \&

WolfF, supra note 6 , at ch. 6.

61. See generally Doty \& Sullivan, supra rote 37, at 246-49 (Spring, 1983)

(suggesting arbitration by an agency

board)

62. See, e.g., Mo. AnN. Stat. \$198.099

(Vernon Supp. 1984); N.J. STAT. ANN

$\$ 26: 2 \mathrm{H}-38$ (West Supp. 1984-85)

63. See Spring v. Geriatric Authority of Holyoke, Sup. 475 N.E.2d 727 (Mass 1985) (plaintiff has statutory cause of action for invasion of privacy). Complaint is repro duced and trial decision is discussed in Goldberg, Harkins, Recent Developments in Long-Term Care Litigation, in LONGTerm Care and THE Law, supra note 36.

64. See, e.g., Stiffelman v. Abrams, 655 S.W.2d 522 (Mo. 1983). In this case, the Supreme Court of Missouri held that Missouri's statutory private right of action sur vived the resident's death and could be pursued by the resident's surviving family This ruling allowed recovery for injuries to the resident himself, including pain and suffering, even though Missouri's statute on wrongful death prohibited recovery for these damages once the resident had died. Id. at 534

65. See, e.g., Mich. Stat. ANN

$\$ 14.15(21799$ C) (Callaghan 1980).

66. Institute of Medicine, Case Study of Georgia (Draft) at 16

67. See Bureaucracy of CARE, supra

note 21 , at $121-24$

68. Doty \& Sullivan, supra note 37 , at 231.

69. D.B. SMITH, LONG-TERM CARE IN Transition: The Regulation of Nursing Homes (AUPHA Press, Washington, D.C.) (1981) at 141 [hereinafter referred to as Care in Transition.

70. Case study of Georgia, supra note 66 , at 16

71. Case Study of California, supra note 17 , at 12

72. Institute of Medicine, Case Study of Texas (Draft) at 6; Case Study of Georgia, supra note 66 , at 7-8.

73. CARE IN TRANSition, supra note 68 , at 143 .

7.4. Mich. Stat, ANN $\$ 14.15(21763-4)$ (Callaghan 1980).

75. Esther Houser, Oklahoma State Long-Term Care Ombudsman, has stated that she does not support access to patient records by volunteers. Dorothy Erickson, director of a volunteer ombudsman pro. gram in St. Louis, stated that "I feel if the ombudsman pulls a record without the res idents' permission, the ombudsman is rip ping off the residents' rights." Wolff, Houser, Erickson, Long-Term Care Ombudsmen, in LONG-TERM CARE AND THE LAw, supra note 36, at 196-97.

76. See Citizens for Better Care v. Reizen, 215 N.W.2d 576 (Mich. App. 1974) (plaintiffs used the state's administrative procedures act to gain access to state rec ords)

77. The Missouri statute requires a facil ity to post a copy of the most recent in spection report when the facility has re ceived a notice of non-compliance. This notice does not issue, however, until the agency has informed the facility of the de ficiencies, the facility has had an opportunity to submit a plan of correction, and the facility has failed either to submit an ade quate plan or fulfill an approved plan These steps delay access to the information significantly. Mo. ANN. STAT. $\$ 198.026$ (Vernon 1985)

78. Care in Transition, supra note 69 , at 133 .

79. See generally' Hawes, Quality' Assur ance in Long-Term Care: Major Problems and Issues (1983) at 1 (Briefing Paper for the Institute of Medicine)

80. See, e.g., Case Study of Georgia, su pra note 66 , at 27 . This issue also surfaced in the public hearings conducted by the Institute

81. Rango, N., Nursing-Home Care in the United States: Prevailing Conditions and Policy' Implications, NeW ENGLAND JOURNAL OF MEDICINE 307(14): 883, 884-85 (September 30, 1982).

82. Id. at 887.

83. Jost, supra note 36 , at 326.

84. Johnson, Terry and Wolff, supra note $6, \$ 1-17$ (1985).

85. MOdEL RECOMMENDATIONS, supra note 1 , at 24-25.

86. Care in Transition, supra note 68 , at 134 .

87. Fia. Stat. AnN. $\$ 400.23$ et seq. (Supp 1985).

88. Although the state licensing power could support a statute authorizing suspen sion of all admissions, California, at present, lacks the ability to suspend admis sions of private pay residents. See $\mathrm{Bu}$ REAUCRACY OF CARE, supra note 21, at 177.

89 Case Study of Georgia, supra note 66 , at 6 .

90. Regulation and FUnding of Illi. NOIS NuRsing Homes, supra note 15 , at 91

91. Case Study of California, supra note 17 , at 12 .

92. Id. at 116-17.

93. Id. at 152.

94. Regulation and Funding OF Ill NOIS NuRsing Homes, supra note 15 , at $71-$ 75 .

95. Id. at 71

96. See +2 U.S.C. $\$ 1396 a(1)$ (1982). 